\title{
Article
}

\section{Determinants of halal-food consumption in Indonesia}

\author{
Vanany, Iwan, Soon, Jan Mei, Maryani, Anny and Wibawa, Berto \\ Mulia \\ Available at http://clok.uclan.ac.uk/27730/ \\ Vanany, Iwan, Soon, Jan Mei ORCID: 0000-0003-0488-1434, Maryani, Anny \\ and Wibawa, Berto Mulia (2019) Determinants of halal-food consumption in \\ Indonesia. Journal of Islamic Marketing . ISSN 1759-0833
}

It is advisable to refer to the publisher's version if you intend to cite from the work. http://dx.doi.org/10.1108/JIMA-09-2018-0177

For more information about UCLan's research in this area go to http://www.uclan.ac.uk/researchgroups/ and search for < name of research Group>.

For information about Research generally at UCLan please go to http://www.uclan.ac.uk/research/

All outputs in CLoK are protected by Intellectual Property Rights law, including Copyright law. Copyright, IPR and Moral Rights for the works on this site are retained by the individual authors and/or other copyright owners. Terms and conditions for use of this material are defined in the policies page.

\section{CLoK}

Central Lancashire online Knowledge www.clok.uclan.ac.uk

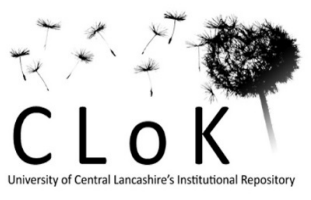




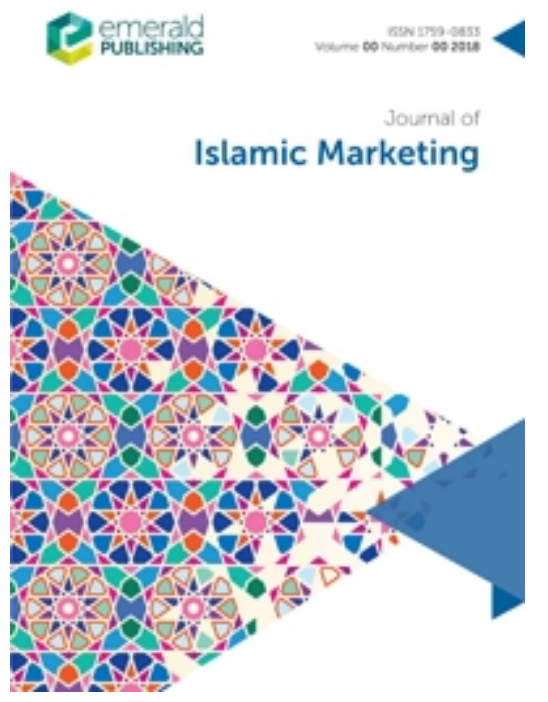

\section{Determinants of halal food consumption in Indonesia}

\begin{tabular}{|r|l|}
\hline Journal: & Journal of Islamic Marketing \\
\hline Manuscript ID & JIMA-09-2018-0177.R1 \\
\hline Manuscript Type: & Research Article \\
\hline Keywords: & $\begin{array}{l}\text { attitude, halal, moral obligations, religious self-identity, Theory of } \\
\text { Planned Behaviour }\end{array}$ \\
\hline \multicolumn{2}{|l}{} \\
\hline
\end{tabular}

\section{SCHOLARONE \\ Manuscripts}


Abstract

5

6 Purpose: Indonesia has the largest Muslim population in the world and represents a

7 significant global market opportunity for halal food producers. Surprisingly, halal food

8 consumption in Indonesia remain under-researched. Thus, this study aims to investigate the

9 factors influencing consumers' halal food consumption using an extended Theory of Planned

Behaviour model.

11

Methodology: Data were collected through a self-administered questionnaire consisting of 418 consumers in Surabaya, Indonesia. Multiple regression analyses were used to describe the Theory of Planned Behaviour (TPB) relationship and halal food consumption.

Findings: This study successfully extended the TPB to include additional predictors: perceived awareness, habit, religious self-identity (RSI), moral obligations and trust to determine consumers' intention in halal food consumption. Attitudes, RSI and moral obligations were significant predictors of intention to consume halal food.

Practical implications: The findings can be used by the government and food producers to target specific factors especially positive attitudes, RSI and moral obligations. Indonesia Ulama Council (Majelis Ulama Indonesia), food industry and the media play a critical role in sustaining consumers' positive attitude towards halal food consumption. It is critical for food manufacturers to tailor their marketing strategies and consider promoting Islamic dietary rules when promoting their food products.

Originality/value: This study is one of the first attempts to investigate the determinants of halal food consumption using an extended TPB in Indonesia.

Keywords: attitude; halal; moral obligations; religious self-identity; Theory of Planned

Behaviour

\section{Introduction}


Halal industry is the fastest growing global business (Yusuf and Ab Yajid, 2016) fuelled by the growing Muslim population. The growing market for "meat and money" (Halal meat and Islamic finance) suggests its significance to both Muslims and non-Muslims (Wilson and Liu, 2010, Wilson, 2012). Halal food represents food that are pure and wholesome and free from haram (forbidden) products such as porcine, blood, carrion, dead animals, predatory animals and birds, and amphibious animals (Adam, 2016). Worldwide Muslim population, which equates to 1.8 billion or $23 \%$ of the global population (Desilver and Masci, 2017) drives the demand for halal food and services. More than $60 \%$ of the Muslim population is in Asia and $20 \%$ in the Middle East and North Africa (Pew Research Center, 2009). For example, 4 out of 5 countries with the largest Muslim populations are based in Asia i.e. Indonesia, Pakistan, India and Bangladesh. Halal has always been associated with food free from pork and alcohol (Alzeer et al., 2018). However, one should understand that halal is driven by values, integrity and trust and affects all aspects of a Muslim's life.

Today, it encompasses service or process such as finance, logistics, standards, auditing and tourism. Halal tourism is worth about $11 \%$ of the total global travel expenditure and is projected to reach USD 233 billion by 2020 (Salam Standard, 2016). Halal tourism adheres to the values of Islam where the goods and services are halal compliant (Mohsin et al., 2016). This obviously includes meeting the dietary requirements of the tourists. The availability of halal food will influence the selection of destination (Bon and Hussain, 2010) and underscores the importance of halal food trade. Besides food, other consumption items include cosmetics, fashion and pharmaceutical products. Apart from finance, which is worth $\$ 2$ trillion, halal food industry contributes one third or $\$ 1.2$ trillion to the global halal economy (Figure 1). This highlights the demand for halal food in the Islamic economy. Farm and food manufacturers, food service providers, logistics and transportation, standards and food safety and quality certification bodies can potentially tap into the booming halal industry.

Insert Figure 1 here

Figure 1. \% spent on halal industry (total $=\$ 3.89$ trillion) (Adapted from: Thomson Reuters, 2017)

The Theory of Planned Behaviour (TPB) identifies factors that predict and modify behaviours (Ajzen, 1985). The factors are measured based on a person's attitudes, subjective norms (i.e. influence from other individuals) and perceived behavioural control (PBC). Attitude refers to the degree of favourable or unfavourable evaluation towards a 
behaviour. Subjective norm refers to perceived social pressure to comply with expectations from other individuals and perceived behavioural control is the feeling of being in control or the confidence in performing a behaviour (Syed and Nazura, 2011). TPB has been used to determine consumers' intention to purchase and consume halal food products. Sherwani et al. (2018) investigated the factors influencing halal meat consumption among Muslims minority in Germany while Bonne et al. (2007) explored the ethnic minority of Muslims population in France. Bonne et al. (2007) further explored the role of self-identity and dietary acculturation in the host country. Ali et al. (2018) identified positive attitude, personal conviction, motivation to comply and perceived control and availability of halal meat predict the intention to eat halal meat among Chinese Muslims in China. Meanwhile nor Sara et al. (2014) revealed that factors such as trust, confidence and lack of halal awareness may affect Muslim consumer's purchasing intention of halal labelled food products such by non-Muslims. Structural equation modelling was also used to determine influential purchasing behaviour of halal food such as those conducted by Aziz and Chok (2013), Bashir et al. (201988) and Haque et al. (2015).

Consumers' awareness and perceptions towards halal food had been carried out in a number Muslim majority countries including Pakistan (Awan et al., 2015; Salman and Siddiqui, 2011), United Arab Emirates (Ireland and Rajabzadeh, 2011) and Malaysia (Khalek, 2014; Mathew et al., 2014; Nor Sara et al., 2014; Rezai et al., 2009, 2012; Said et al., 2014; Syed et al., 2011; Wibowo and Ahmad, 2016). Several halal-based studies conducted in Indonesia relates to halal certifications and exporters' views of the Indonesian market (Prabowo et al., 2015; Ratanamaneichat and Rakkarn, 2013), business opportunities (Soesilowati, 2011), halal labelling (Luthi and Salehudin, 2011) but limited studies on consumers' perception of halal food (Ismoyowatu, 2015). Indonesia has the largest Muslim population in the world and represents a significant proportion of market opportunity for local and international food producers and exporters. However, there is still a paucity of research looking into the factors that drive halal food consumption among the population. How does religion shape and influence the people's values and behaviours in Indonesia? Can one determine consumers' food habits based on their attitude, social norms and perceived control?

Sherwani et al. (2018) proposed a theoretical model using the TPB and further explained how the predictive power of TPB was influenced by other factors i.e. religious selfidentity (RSI), dietary acculturation, trust and moral obligations. Bonne et al. (2008) added RSI into their TPB framework to predict halal meat consumption among Muslims in Belgium. Self-identity influences one's behaviour as individuals seek to perform behaviours that best 
reflect their sense of self. Religious self-identity is influenced by the extent to which one believes and engages in the teachings and identifies as being affiliated with a religion (Minton et al., 2019in press). For example, the influence of self-identity as a Muslim encourages one to eat halal food if one sees oneself as religious-conscious (Biddle et al., 1987; Conner and Armitage, 2006). Halal-conscious customers tend to be more selective and have high-involvement behaviour in selection and purchasing of food and materials as they are also more risk averse (Wilson and Liu,2011)

Religion is at the heart of Indonesian people's lives. There is also an obligation for Indonesians to choose and embrace one of the six official religions - Islam, Christianity, Catholic, Hinduism, Buddhism and Confucianism (Briliana and Mursito, 2017). Religious selfidentity and its' effects had been studied by various researchers (Ali et al., 2018; Bonne et al., 2007; Ireland and Rajabzadeh, 2011; Sherwani et al., 2018). The studies revealed how religion shape and impact upon consumers' food choices. Religion also impacts on consumers' likes and dislikes (Briliana and Mursito, 2017) and is reflected in the individuals' attitudes and behaviour. Hence, factors such as RSI, moral obligation and trust were investigated in this study and is predicted to significantly affect halal food consumption. Habits are routines repeated regularly and tend to occur subconsciously. Habits had been successfully incorporated into TPB models to predict food-related behaviour (Ahmed et al., 2014; Verbeke, 2005). Awareness represents the perception and cognitive reaction to events and objects (Ambali and Bakar, 2014) and has an influence on intention. It can also be defined as knowledge, consciousness and familiarity gained by experience or learning (Hamdan et I., 2013). Previous studies reported awareness as a significant factor in halal purchase intention (Ambali and Bakar, 2014; Aziz and Chok, 2013). Habits and perceived awareness were also measured to improve the predictive power of the model.

Considerable evidence had been reported on halal food purchasing and/or consumption among Muslim consumers in non-Muslim countries (Bonne et al., 2007; Elseidi, 2018; Verbeke et al., 2013). Surprisingly, there were very few studies (apart from Malaysia) investigating the factors of halal food consumption among Muslims in developing countries. Thus, this study aims to investigate the factors influencing consumers' halal food consumption using an extended TPB model. Using the TPB and Sherwani et al. (2018) as a guide, the authors predicted that positive attitudes, strong subjective norms and greater perceived control directly affects halal food consumption. Similarly, the authors predicted that positive relationships between perceived awareness, religious self-identity, habit, moral obligations and trust significantly affect their intention to consume halal food. 
140 Methodology

\section{Questionnaire development}

142 The questionnaire was developed and consist of four sections: i) demographics (5 143 questions); (ii) Theory of Planned Behaviour factors i.e. attitude, subjective norms, 144 perceived behavioural control and behavioural intention (15 questions) (Armitage and 145 Conner 1999; Han et al., 2010; Hoeksma et al., 2017; Kim and Han 2010); (iii) perceived 146 awareness (3 questions) and (iv) additional factors (13 questions). Additional factors such as 147 perceived awareness, habit (Honkanen et al., 2005), moral obligations (Haines et al. 2007), 148 religious self-identity (Terry et al., 1999) and trust (Teng and Wang, 2015) were also 149 explored after reviewing current literature. Questions were measured on a 5-point Likert 150 scale of strongly disagree / extremely unimportant (1) to strongly agree / extremely 151 important (5). The questions were translated into Indonesia/Melayu-Malay and back152 translated into English by the first and second authors. A pilot study was conducted among 15315 participants not included in the actual survey to determine the suitability and clarity of 154 the questions.

\section{Data collection}

The survey was conducted among consumers in Surabaya, Indonesia from March - May 2018. Surabaya is the second largest city in Indonesia and has a population of 2,948,000 of which $85 \%$ are Muslims (World Population Review, 2018). Consumers that crossed a designated spot were approached to participate in the survey. The purpose of the study was explained to them. For those who were interested to participate, consent was obtained and a paper-based questionnaire was distributed. A total of 418 questionnaires were returned.

\section{Statistical analysis}

Descriptive statistics were used to determine the frequency of distribution of all sociodemographic characteristics. The internal consistency of the questionnaire was evaluated using Cronbach's alpha. Independent t-tests and one-way analysis of variance were conducted using SPSS 24.0 (IBM SPSS). To test the hypotheses, multiple regressions were conducted to predict the intent to consume halal food and confidence level was set at $95 \%$.

\section{Results and Discussion} Male makes up more than half of the respondents (55.30\%). Most respondents were graduates (54.10\%) and 27.00\% earned between 3,500,001 - 5,000,000 Indonesian Rupiah 
(IDR) (US \$ 245 - 350). The minimum salary in Surabaya is 3,583,312 IDR (Faizal, 2017).

The high number of respondents from the graduates coincide with the local demographics. There are 35 major universities and institutions in the city and the population is relatively well-educated. The age demographics were divided equally between the millennials (18 - 35 years) (40.20\%) and Generation X (36 - 55 years) groups (44.30\%). The last age group the baby boomers (56 years and above) made up the rest of the $15.60 \%$. Homemakers (19.60\%), students (15.10\%) and private employees (15.10\%) made up the top three occupations among the respondents.

The respondents mostly agreed with the factors for consuming halal food with desirable attitude averaging the highest score (4.64 \pm 0.62$)$. The study also revealed that respondents did not feel under pressure to eat halal food (2.22 \pm 1.24$)$. One-way ANOVA revealed significant difference between millennials and Gen-X respondents in their attitude towards halal food consumption. Millennials strongly agreed that consuming halal food is extremely important $(F(2,415)=5.09, p=0.006)$ and desirable $(F(2,415)=5.36, p=0.003)$. The attribute measuring subjective norms revealed that both millennials and baby boomers strongly agreed that people who matters to them would approve them eating halal food ( $F$ $(2,415)=4.71, p=0.02)$. The different age groups did not differ significantly in their habits except that the youngest and oldest groups do not have to consciously remember that they should be consuming halal food $(F(2,415)=4.06, p=0.02)$. Although all age groups agreed that they will feel morally wrong if they do not consume halal food, however baby boomers felt sless strongly compared to the younger generations $(F(2,415)=3.54, p=0.03)$ (Table 1). Having a university or college degree did not make any significant differences in the respondents' attitudes or social norm. However, the group with higher education (i.e. degree or postgraduate studies) felt that they have more control over consumption of halal food ( $t$ $(416)=2.30, p=0.02)$ and felt very weird for not consuming halal food $(t(416)=2.56$, $p=0.01)$. The highly educated group also scored significantly higher in their intention to purchase halal food in future $(t(416)=3.63, p<0.0001)$. This contradicts Soesilowati $(2010)$ where the author found no relation between an individual's level of education and concerns about halal food consumption. There was no significant difference between male and female in all attributes.

Please insert Table 1 here Table 1 Factors influencing consumption of halal food $(n=418)$ 
209 Multiple linear regressions were performed to evaluate the TPB model for halal food 210 consumption. Cronbach alpha scores for attitudes, PBC, RSI and moral obligations were 211 excellent, demonstrating consistency between subjects when answering the questions. The 212 Cronbach alpha for subjective norms, perceived awareness and trust ranged from 0.51 2130.59 but were still acceptable (Table 2). The ICC values range between 0 and 1 , with values 214 above 0.8 considered excellent reliability, $0.6-0.8$ good, $0.4-0.6$ moderate, and less than 0.4 as low reliability (Landis and Koch 1977).

216

Please insert Table 2 here

Table 2 Mean composition of items and reliability analysis of TPB components

219

Intention to perform the behaviour was predicted from the first model consisting of attitude, subjective norms and PBC (Figure 1). The regression model explained about $24 \%$ of the variance of the intent to consume halal food where $R^{2}=0.24$, (Adjusted $R^{2}=0.23$ ). This was significantly different where $F(3,386)=40.47, p<0.001$. All predictors (attitude, SN, PBC) contributed significantly to the prediction of halal food consumption (Figure 12 ). This supports the first hypothesis that consumers with positive attitudes, strong social pressure and increased perceived control were more likely to consume halal food. Other studies had successfully used TPB as a theoretical framework to explain behavioural intention. Alam and Sayuti (2011)'s TPB model explained $29.1 \%$ of the variance in halal food purchasing intention. Additional predictors must be sought as more than $70 \%$ of the variance remain unexplained.

231

232 Please insert Figure $1 \underline{2}$ here

233 Figure $12 \underline{2}$ Theory of Planned Behaviour model (attitude, subjective norms and PBC) of halal 234 food consumption among consumers in Indonesia

235

236

Hence, additional factors (perceived awareness, habit, RSI, moral obligations and trust)

237 were regressed against intention to consume halal food. The second regression model (Figure $2 \underline{3}$ ) accounted an additional $19 \%$ of the variance where $\mathrm{R}^{2}=0.43$, (adjusted $\left.\mathrm{R}^{2}=0.42\right)$. The model was significantly different from zero where $F(8,381)=36.37$, $p<0.001$. In the second model, attitude, RSI and moral obligations were significant predictors of the intention to consume halal food. 
244 Figure 23 Extended Theory of Planned Behaviour model on halal food consumption among

245 consumers in Indonesia

Attitude towards halal food consumption consistently ranked the highest among all factors. It significantly predicts halal food consumption $(\beta=0.12, p<0.05)$. This corroborates with other studies that reported attitude has a significant and positive effect on halal food purchasing intention (Ahmed et al., 2014; Alam and Sayuti, 2011; Bonne et al., 2007; Lada et al., 2009). Consumers who reported high positive attitudes demonstrated greater intentions to consume halal food. Subjective norms did not significantly predict intention to consume halal food. Consumers agreed that social norms play a role in determining their food choices. Although respondents do not feel under social pressure to eat halal food, 255 however they agreed that people who are important to them would disapprove if they do not consume halal food. Similarly, Salman and Siddiqui (2011) reported that consuming nonhalal food can affect one's social relations and lead to isolation from the Muslim community. Subjective norms can also be explained by the type of cultures ingrained in a country. Muslim culture is a collectivistic culture where people perceived themselves to be interdependent with each other and value in-group recommendations (Jamal, 2003). This is unlike individualistic cultures where people perceived themselves to be autonomous and independent of the group (Bonne et al., 2007).

There is a negative and insignificant relationship ( $B=-0.01$ ) between PBC and intent to consume halal food meaning that perceived control and availability does not influence halal food consumption. In other words, availability is not a barrier to consuming halal food. Similarly, Bonne et al. (2006) reported a negative and insignificant relationship between perceived availability and halal meat consumption. This is in contrast to Verbeke and Lopez (2005) who found that lack of ingredients in markets and high cost deterred Hispanics in Belgium from retaining their native food habits. The findings in this study suggests that consumers are very confident about the availability of halal food. In other Muslim majority country such as Pakistan, it was noted that the government and local authorities are responsible for the availability of halal food (Awan et al., 2015).

There is no significant impact of perceived awareness on halal food consumption. corroborates with Awan et al. (2015) findings. However, this contradicts Aziz and Chok (2013), Azam (2016) and Hamdan et al. (2013), who found that halal awareness was an influential factor in determining halal food purchasing intention. As awareness can be a relative concept, it is worth exploring the level of awareness (i.e. partially, subconsciously 
and acutely) and its influence on halal food consumption. Eating halal food is a habituated process as indicated by the high scores on the habit items. This aligns with Ahmed et al. (2014) where the consumers consider halal food consumption as an automated process. However, habit did not significantly predict halal food consumption and this may have been caused by consumers' uncertainty about one of the items i.e. 'I don't have to think about doing it'. It is common for Muslim consumers to read food labels or to look for halal indicators such as halal guarantee status, country of origin and product ingredients when purchasing and prior to consuming (Ishak et al., 2016).

The attributes for religious self-identity were ranked highly by respondents. Religious self-identity significantly predicts halal food consumption among consumers in Indonesia ( $\beta=0.24, p<0.0001)$. This value indicates that as RSI increases by one unit, halal food consumption intent increases by 0.24 unit. Religion remains an important universal and personal marker of identity. Bonne and Verbeke (2006) revealed that Muslim consumers eat halal food to follow and express their religious teachings. However, the impact of religion on food consumption depends on the religion itself, the extent of the individuals' interpretation and following of teachings (McWilliams et al., 2016). Indonesia is a Muslim-majority country and observes strong religious socialisation. Muslims are obligated to follow the teachings in Qur'an and consume halal food and avoid haram (non-permissible) food such as porcine, alcohol, blood, carnivorous animals, birds of prey and any food contaminated with these products (Soon et al., 2017). This helps to cement the consumers' religious self-identity and motivation to follow the Islamic dietary laws. Previous studies also showed that RSI influenced the decision-making process in halal food consumption. Individuals with strong religion identification were more motivated to follow halal dietary rules (Bonne and Verbeke, 2006; Bonne et al., 2008; Heiman et al., 2004; Johnson et al., 2011). A similar study by Soesilowati (2010) revealed that the higher the degree of an individual's religiosity, the greater their concern are to consume halal food. The degree of an individual's religiosity is also influenced by religious experience and education background especially if the respondents were educated in Islamic boarding schools in Indonesia (Soesilowati, 2010) Prior studies identified religion as a source of core values including moral principles that influence consumption habits (Mathras et al., 2016; Vitell, 2009). This study corroborates with previous findings and moral obligations were shown to be a significant predictor in halal food consumption $(\beta=0.32, p<0.0001)$. Respondents are convinced that food products with halal logos are indeed halal. Provision of false information of halal food products can cause mistrust and loss of confidence among consumers (Mohamed et al., 2013). 


\section{Practical implications}

Indonesia is currently the leading country with the highest Muslim population and makes up $12.7 \%$ of the global Muslim population in 2010 (Pew Research Center, 2011). Indonesia contributes to the food and agricultural economy by importing more than US\$12 billion worth of agricultural products (FAOSTAT, 2016). The findings provided in this study can be used by the government and food producers to target specific factors especially positive attitudes, RSI and moral obligations. Indonesian Ulaema Council (Majelis Ulama Indonesia a Muslim clerical body), food industry and the media play critical roles in sustaining consumers' positive attitude towards halal food consumption. Halal is an opportunity for the expansion of products and brands, making it as it a niche marketing approach (Wilson,2014) and also need-to ensure the integrity of the supply chain (Soon et al., 2017). Ensuring the integrity of the halal food supply chain will ensure the success of halal market. If consumers' trust towards halal food are breached (e.g. contamination of food products with haram sources), this may create negative feelings among consumers and reduced confidence in the market. Secondly, the findings revealed that RSI and moral obligations are significant predictors in their intent to consume halal food. This provides clear implication to halal food manufacturers. It is critical for food manufacturers to tailor their marketing strategies and consider promoting Islamic dietary rules when featuring their food products. With assistance from Indonesian Ulama Council - a trusted halal certifier, local manufacturers can set up their halal assurance system (HAS) to achieve halal certification Ratanamaneichat and Rakkarn (2013). Similarly, local food services could prioritise halal certification. Prabowo et et al. (2015) revealed that food services places less concern in achieving halal certification due to lack of socialisation and information leading to lack of knowledge and awareness. To participate in the global halal market, companies can incorporate halal certification and labelling. With the surge in halal economy and demand for halal goods, halal certification bodies play an important role in ensuring the integrity of the supply chain. As Indonesia is one of the fastest growing halal economy globally, Indonesia can emulate other 342 Organisation of Islamic Cooperation (OIC) countries to market and certify their food 343 products.

\section{Conclusion}

346 This study extended the Theory of Planned Behaviour to incorporate additional factors to 347 predict the intent to consume halal food. This study also answered the call from previous 348 literature regarding the lack of research in halal food in other Muslim majority countries. 
Findings from this study provided evidence of significant relationships between attitude, RSI and moral obligations with halal food consumption among consumers in Indonesia. These factors can be targeted in marketing-related strategies by food manufacturers and exporters. Additionally, the results can be used by the Surabayan authorities, policymakers and academia in managing the direction of halal food production and development. Future studies should be carried out to further explore each predictor in detail.

\section{References}

Ajzen, I. (1985), "From intentions to actions: A Theory of Planned Behaviour", in, J. Kuhl and J. Beckmann (eds.). Action Control: From Cognition to Behaviour. Springer Berlin Heidelberg, pp. 11-39.

Ahmed, Z. U., Al-Kwifi, O. S., Saiti, B. and Othman, N. (2014), "Consumer behaviour dynamics of Chinese minorities", Journal of Technology Management in China, Vol. 9 No. 1, pp. 6-23.

Alam, S. S. and Sayuti, N. M. (2011), "Applying the Theory of Planned Behavior (TPB) in halal food purchasing", International Journal of Commerce and Management, Vol. 21 No. 1, pp. 8-20.

Ali, A., Ali, A., Xiaoling, G., Sherwani, M. and Hussain, S. (2018), "Expanding the theory of planned behaviour to predict Chinese Muslims halal meat purchase intention", British Food Journal, Vol. 120 No. 1, pp. 2-17.

Alzeer, J., Riefer, U. and Hadeed, K. A. (2018), "Rational and practical aspects of halal ad tayyib in the context of food safety", Trends in Food Science and Technology, Vol. 71, pp. 264-267.

Ambali, A. R. and Bakar, A. N. (2014), "People's awareness on halal foods and products: Potential issues for policy-makers", Procedia - Social and Behavioural Sciences, Vo. 121, pp. 3-25.

Armitage, C. J. and Conner, M. (1999), "The theory of planned behaviour: Assessment of predictive validity and 'perceived control'", British Journal of Social Psychology, Vol. 38, pp. 35-54.

Awan, H., Siddiquei, A. N. and Haider, Z. (2015), "Factors affecting halal purchase intention - evidence from Pakistan's halal food sector", Management Research Review, Vol. 38 No. 6, pp. 640-660.

Azam, A. (2016), "An empirical study on non-Muslim's packaged halal food manufacturers: Saudi Arabian consumers' purchase intention", Journal of Islamic Marketing, Vol. 7 No. 4, 441-460.

Aziz, Y. A. and Chok, N. V. (2013), "The role of halal awareness, halal certification, and marketing components in determining halal purchase intention among non-Muslims in Malaysia: A structural equation modeling approach", Journal of International Food \& Agribusiness Marketing, Vol. 25 No. 1, pp. 1-23. 
Bashir, A. M., Bayat, A., Olutuase, S. O. and Abdul Latiff, Z. A. (2019),-"Factors affecting consumers' intention towards purchasing halal food in South Africa: a structural equation modelling ${ }^{\prime \prime}$ - Journal of Food Products Marketing, Vol. 25 No. 1, pp. 26-48. doi: 10.1080/10454446.2018.1452813

Biddle, B. J., Bank, B. J. and Slavings, R. L. (1987), "Norms, preferences, identities and retention decisions", Social Psychology Quarterly, Vol. 50 No. 4, pp. 322-337.

\section{Bon, M. and Hussain, M. (2010), "Halal food and tourism: Prospects and challenges", Bridging Tourism Theory and Practice, Vol. 2, pp. 47-59.}

Bonne, K. and Verbeke, W. (2006), "Muslim consumer's motivations towards meat consumption in Belgium: qualitative exploratory insights from means-end chain analysis", Anthropology of Food, Vol. 5, pp. 2-24.

Bonne, K., Vermeir, I., Bergeaud-Blackler, F. and Verbeke, W. (2007), "Determinants of halal meat consumption in France", British Food Journal, Vol. 109 No. 5, pp. 367-386.

Bonne, K., Vermeir, I. and Verbeke, W. (2008), "Impact of religion on halal meat consumption decision making in Belgium", Journal of International Food \& Agribusiness Marketing, Vol. 21 No. 1, pp. 5-26.

Briliana, V. and Mursito, N. (2017), "Exploring antecedents and consequences of Indonesian Muslim youths' attitude towards halal cosmetic products: A case study in Jakarta", Asia Pacific Management Review, Vol. 22 No. 4, pp. 176-184.

Conner, M. T. and Armitage, C. J. (1998), "Extending the theory of planned behaviour: A review and avenues for further research", Journal of Applied Social Psychology, Vol. 28, pp. 1429-1464.

DeSilver, D. and Masci, D. (2017), "World's Muslim population more widespread than you might think. Pew Research Center", available at: http://www.pewresearch.org/facttank/2017/01/31/worlds-muslim-population-more-widespread-than-you-might-think/ [Accessed 27 January 2018].

Elseidi, R. I. (2018), "Determinants of halal purchasing intentions: evidences from UK", Journal of Islamic Marketing, Vol. 9 No. 1, pp. 167-190.

Faizal, A. (2017), "UMK Surabaya 2018 sebesar Rp 3,58 juta jadi tertinggi di jatim", Available at:https://regional.kompas.com/read/2017/11/21/17284231/umk-surabaya-2018sebesar-rp-358-juta-jadi-tertinggi-di-jatim [Accessed 17 August 2018]

FAOSTAT (2016), "Crops and livestock products", available at:

http://www.fao.org/faostat/en/\#data/TP [Accessed 16 August 2018]

Haines, R., Street, M. D. and Haines, D. (2008), "The influence of perceived importance of an ethical issue on moral judgment, moral obligation and moral intent", Journal of Business Ethics, Vol. 81, pp. 387-399 
Hamdan, H., Mat Issa, Z., Abu, N. and Jusoff, K. (2013), "Purchasing decision among Muslim consumers of processed halal food products", Journal of Food Products Marketing, Vol. 19 No. 1 , pp. 54-61. Han, H., Hsu, L.-T. and Sheu, C. (2010), "Application of the Theory of Planned Behavior to green hotel choice: Testing the effect of environmental friendly activities", Tourism Management, Vol. 31 No. 3, pp. 325-334.

Haque, A., Sarwar, A., Yasmin, F., Tarofder, A. K. and Hossain, M. A. (2015), "Non-Muslim consumers' perception toward purchasing halal food products in Malaysia", Journal of Islamic Marketing, Vol. 6 No. 1, pp. 133-147.

Heiman, A., Just, D., McWilliams, B. and Zilberman, D. (2004), "Religion, religiosity, lifestyles and food consumption", Agriculture Resource Economics, Vol. 8 No. 2, pp. 9-11.

Hoeksma, D. L., Gerritzen, M. A., Lokhorst, A. M. and Poortvliet, P. M. (2017), "An extended theory of planned behaviour to predict consumers' willingness to buy mobile slaughter unit meat", Meat Science, Vol. 128, pp. 15-23.

Honkanen, P., Olsen, S. O. and Verplanken, B. (2005), "Intention to consume seafood - the importance of habit", Appetite, Vol. 45 No. 2, pp. 161-168.

Ireland, J. and Rajabzadeh, S. A. (2011), "UAE consumer concerns about halal products", Journal of Islamic Marketing, Vol. 2 No. 3, 274-283.

Ishak, S., Awang, A. H., Hussain, M.Y., Ramli, Z., Md Sum, S., Saad, S. and Manaf, A. A. (2016), "A study on the mediating role of halal perception: determinants and consequence reflections", Journal of Islamic Marketing, Vol. 7 No. 3, pp. 288-302.

Ismoyowati, D. (2015), "Halal food marketing: A case study on consumer behavior of chicken-based processed food consumption in Central Part of Java, Indonesia", Agriculture and Agricultural Science Procedia, Vol. 3, pp. 169-175.

Jamal, A. (2003), "Marketing in a multicultural world: The interplay of marketing, ethnicity and consumption", European Journal of Marketing, Vol. 7, pp. 70-78.

Johnson, K. A., White, A. E., Boyd, B. M. and Cohen, A. B. (2011), "Matzah, meat, milk, and mana: Psychological influences on religious food practices", Journal of Cross-Cultural Psychology, Vol. 42 No. 8, pp. 1421-1436.

Kim, Y. and Han, H. (2010), "Intention to pay conventional-hotel prices at a green hotel: A modification of the theory of planned behaviour", Journal of Sustainable Tourism, Vol. 18, pp. 997-1014.

Lada, S., Tanakinjal, G. H. and Amin, H. (2009), "Predicting intention to choose halal products using theory of reasoned action", International Journal of Islamic and Middle Eastern Finance and Management, Vol. 2 No. 1, pp. 66-76.

Luthfi, B. A. and Salehudin, I. (2011), "Marketing impact of halal labeling toward Indonesiamn Muslim consumer's behavioural intention based on Ajzen's planned behaviour theory: Policy capturing studies on five different product categories", ASEAN Marketing Journal, Vol. 3 No. 1, pp. 35-43. 
500

501

502

503

504

505

506

507

508

509

510

511

512

513

514

515

516

517

518

519

520

521

522

523

524

525

526

527

528

529

530

531

532

533

534

535

536

537

538

539

540

541

542

543

544

545

546

547

548

549

550

551
Mathras, D., Cohen, A. B., Mandel, N. and Mick, D. G. (2016), "The effects of religion on consumer behaviour: A conceptual framework and research agenda", Journal of Consumer Psychology, Vol. 26 No. 2, pp. 298-311.

McWilliams, B., Heiman, A., and Zilberman, D. (2016), "Discussion Paper No. 516. Religion, religiosity, and the consumption of timesaving foods", available at:

http://departments.agri.huji.ac.il/economics/en/publications/discussion_papers/2016/5.16Mc WilliamsHeimanZilberman-Religion-Religiosity.pdf [Accessed 16 August 2018].

Minton, E. A., Johnson, K. A and Liu, R. L. (2019in press), "Religiosity and special food consumption: The explanatory effects of moral priorities", Journal of Business Research, Vol. 95, pp. 442-454. doi: doi.org/10.1016/j.jbusres.2018.07.041

Mohamed, Z., Shamsudin, M. N. and Rezai, G. (2013), "The effect of possessing information about halal logo on consumer confidence in Malaysia", Journal of International Food and Agribusiness Marketing, Vol. 25 No. Supp. 1, pp. 73-86.

\section{Mohsin, A., Ramli, N. and Alkhulayfi, B. A. (2016), "Halal tourism: Emerging opportunities", Tourism Management Perspectives, Vol. 19 (Part B), pp. 137-143.}

Nor Sara, N. M. Y., Wan Edura, W. R., Noradifia, M. A. and Norhidayah, M. R. (2014), "Muslim's purchase intention towards non-Muslim's halal packaged food manufacturer", Procedia - Social and Behavioural Sciences, Vol. 130, pp. 145-154.

Pew Research Center (2009), "Mapping the global Muslim population", The Pew Forum on Religion and Public Life, Washington, D.C.

Pew Research Center (2011), "The future of the global Muslim population", available at: http://www.pewforum.org/2011/01/27/the-future-of-the-global-muslim-population/ [Accessed 16 August 2018]

Prabowo, S., Abd Rahman, A., Ab Rahman, S. and Abu Samah, A. (2015), "Revealing factors hindering halal certification in East Kalimantan Indonesia", Journal of Islamic Marketing, Vol. 6 No. 2, pp. 268-291.

Ratanamaneichat, C. and Rakkarn, S. (2013), "Quality assurance development of halal food products for export to Indonesia", Procedia - Social and Behavioral Sciences, Vol. 88, pp. 134-141.

\section{Salam Standard (2016), "The global economic impact of Muslim tourism, 2015/2016", Available at: http://www.webintravel.com/wp-content/uploads/2016/12/Salam-Standard- Global-Economic-Impact-of-Muslim-Tourism-2015.pdf [Accessed 12 March 2019]}

Salman,F. and Siddiqui, K. (2011), "An exploratory study for measuring consumers awareness and perceptions towards halal food in Pakistan", Interdisciplinary Journal of Contemporary Research in Business, Vol. 3 No. 2, pp. 639-651.

Sherwani, M., Ali, A., Ali, A., Hussain, S. and Zadran, H. G. (2018), "Determinants of Muslim consumers' Halal meat consumption: Applying and extending the theory of planned behaviour", Journal of Food Products Marketing, Vol. 24 No. 8, pp.960-981 doi: $10.1080 / 10454446.2018 .1450173$ 
Soesilowati, E. S. (2010), "Business opportunities for halal products in the global market: Muslim consumer behaviour and halal food consumption", Journal of Indonesian Social Sciences and Humanities, Vol. 3, pp. 151-160.

Soon, J. M., Chandia, M. and Regenstein, J. M. (2017), "Halal integrity in the food supply chain", British Food Journal, Vol. 119 No. 1, pp. 39-51.

Syed, S. A. and Nazura, M. S. (2011), "Applying the Theory of Planned Behaviour (TPB) in halal food purchasing", International Journal of Commerce and Management, Vol. 21 No. 1, pp. 8-20.

Teng, C.-C. and Wang, Y.-M. (2015), "Decisional factors driving organic food consumption: Generation of consumer purchase intentions", British Food Journal, Vol. 117 No. 3, pp. 1066-1081.

Terry, D. J., Gogg, M. A. and White, K. M. (1999), "The theory of planned behaviour: Selfidentity, social identity and group norms", British Journal of Social Psychology, Vol. 36, pp. 225-244.

\section{Thomson Reuters (2017), "State of the global Islamic economy 2016/17", Available at: https://ceif.iba.edu.pk/pdf/ThomsonReuters- stateoftheGlobalIslamicEconomyReport201617.pdf [Accessed 12 March 2019] \\ Verbeke, W. (2005), "Agriculture and the food industry in the information age", European Journal of Agricultural Economics, Vol. 32 No. 3, pp. 347-368.}

Verbeke, W. (2013), "Credence quality coordination and consumers' willingness-to-pay for certified halal labelled meat", Meat Science, Vol. 95 No. 4, pp. 790-797.

Verbeke, W. and Lopez, G. P. (2005), "Ethnic food attitudes and behaviour among Belgians and Hispanics living in Belgium", British Food Journal, Vol. 107 No. 11, pp. 823-840.

Vitell, S. J. (2009), "The role of religiosity in business and consumer ethics: A review of the literature", Journal of Business Ethics, Vol. 90 No. 2, pp. 155-167.

Wilson, J. A. J. (2012), "Charting the rise of the halal market - tales from the field and looking forward", Journal of Islamic Marketing, Vol. 3 No. 3, pp. 18-27.

Wilson, J. A. (2014), "The halal phenomenon: an extension or a new paradigm?" Social Business, Vol. 4 No. 3, pp. 255-271.

Wilson, J. A. J. and, \& Liu, J. (2010),-" "Shaping the Halal into a brand?" Journal of Islamic Marketing, Vol. 1 No. 2, pp. 107-123.

Wilson, J. A. and $\&$ Liu, J. (2011), "-The challenges of Islamic branding: navigating emotions and halal", Journal of Islamic Marketing, Vol. 2 No. 1, pp. 28-42.

World Population Review (2018), "Surabaya population 2018", available at: http://worldpopulationreview.com/world-cities/surabaya-population/ [Accessed 2 July 2018] 
601 Yusuf, E. and Ab Yajid, M. S. (2016), "Halal pharmaceuticals and cosmeceuticals from the 602 perspective of higher education", Asian Journal of Pharmaceutical Sciences, Vol. 11 No. 1, 603 pp. 18-19. 


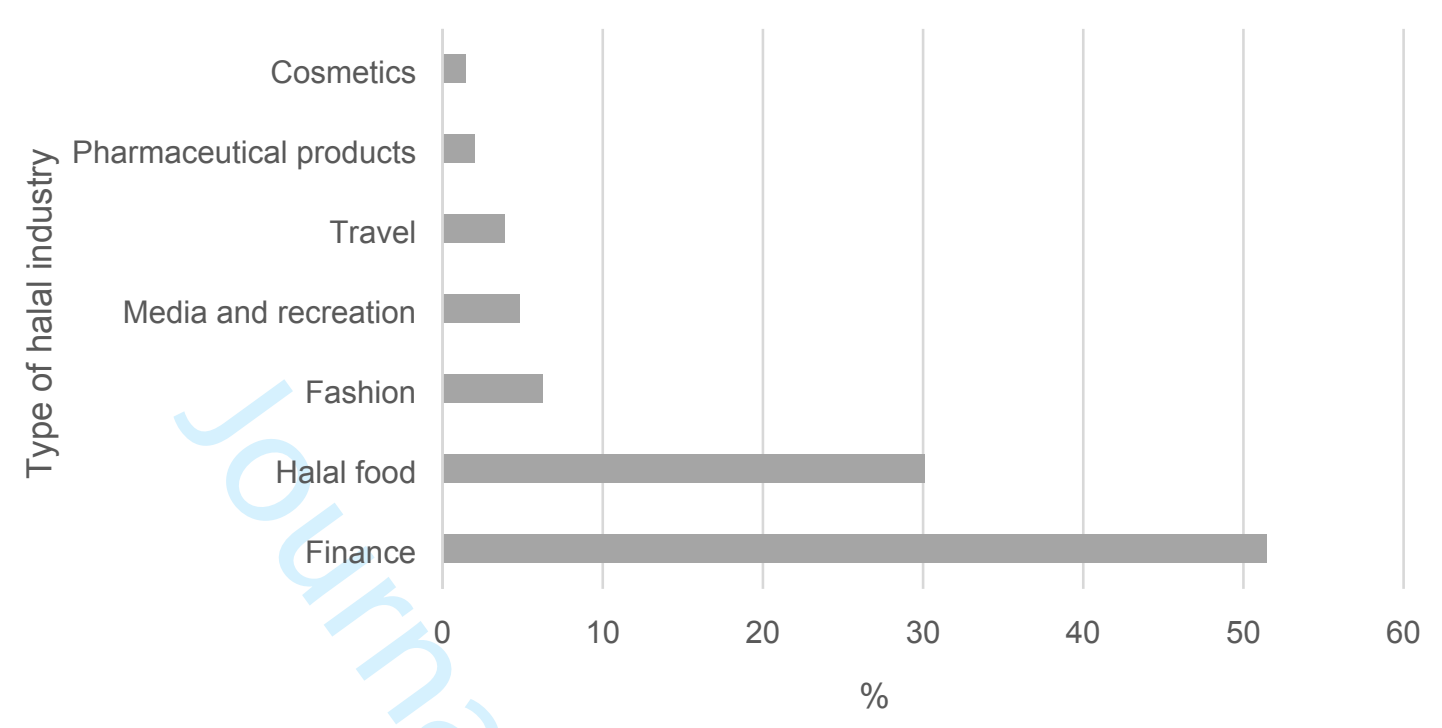

Figure 1 Percentage spent on halal industry (total $=\$ 3.89$ trillion) (Adapted from: Thomson Reuters, 2017) 


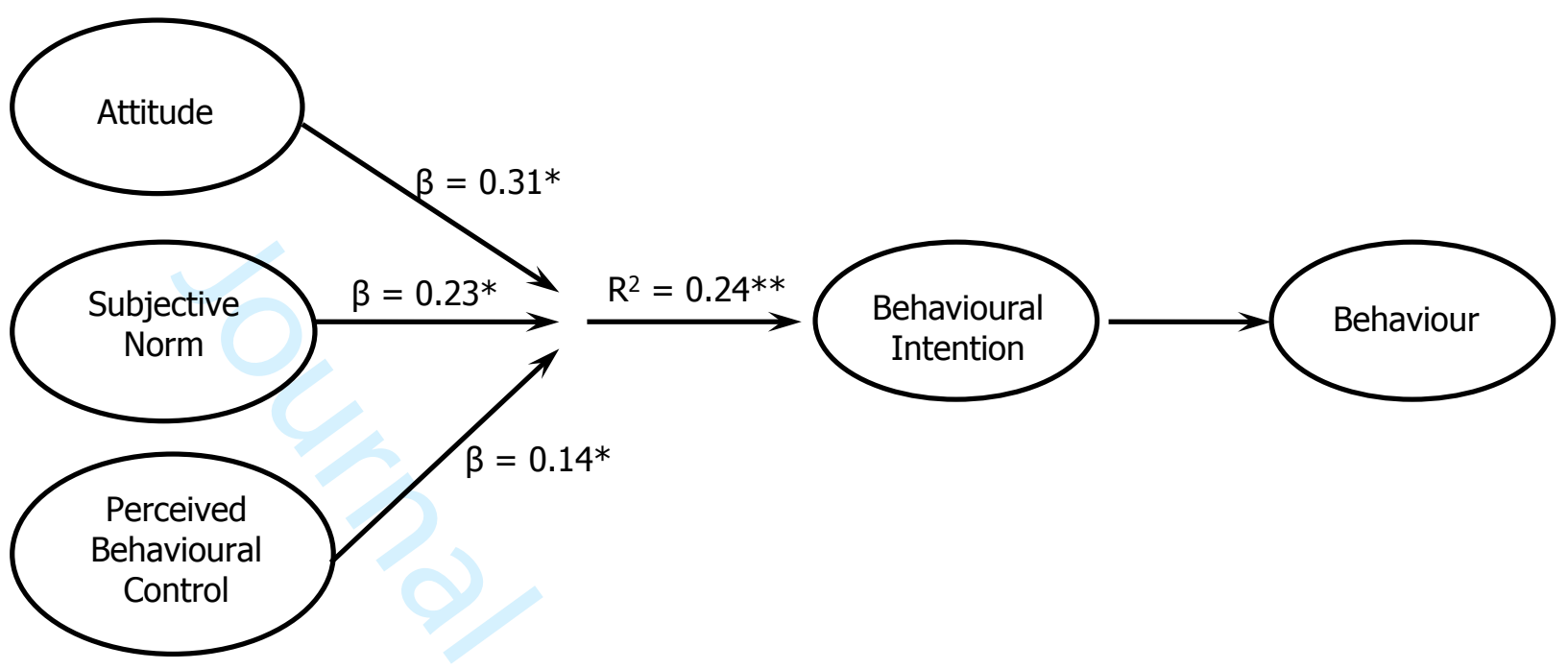

Figure 2 Theory of Planned Behaviour model (attitude, subjective norms and PBC) of halal food consumption among consumers in Indonesia 


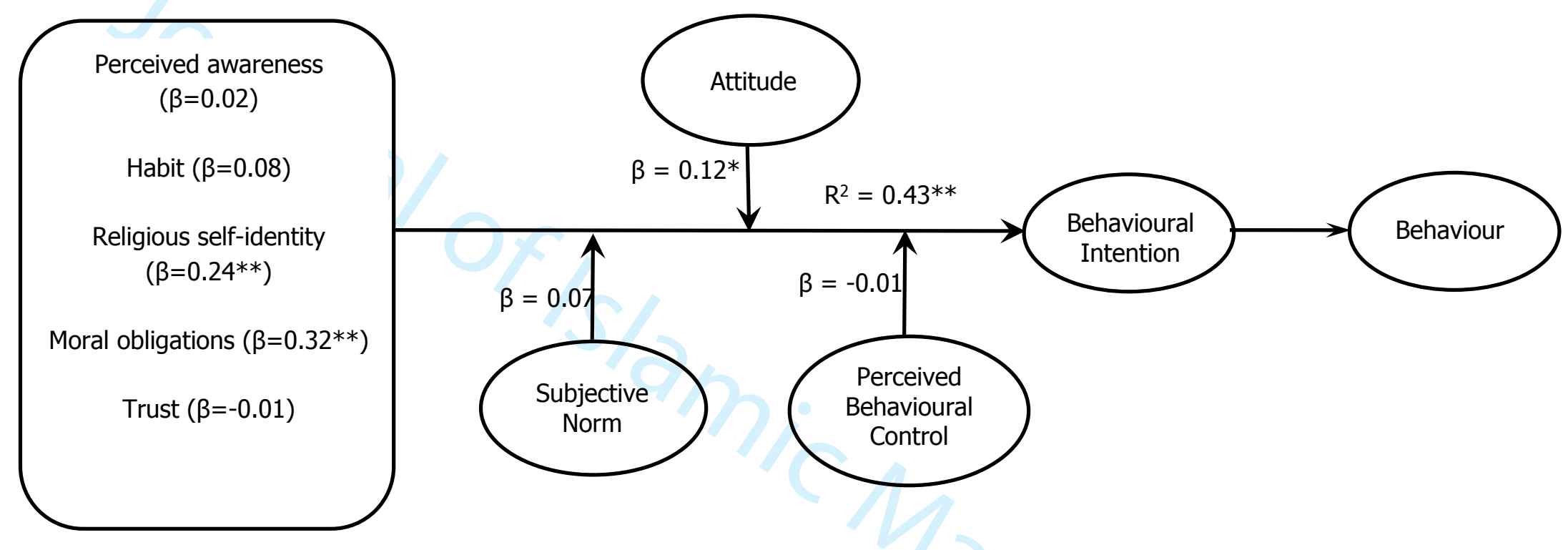

Figure 3 Extended Theory of Planned Behaviour model on halal food consumption among consumers in Indonesia 
Table 1 Factors influencing consumption of halal food $(n=418)$

\begin{tabular}{|c|c|c|c|c|c|c|c|c|}
\hline \multirow[t]{2}{*}{ Factors } & \multicolumn{4}{|c|}{ Age } & \multicolumn{3}{|c|}{ Education } & \multirow{2}{*}{$\begin{array}{c}\text { Overall } \\
\text { mean } \pm \\
\text { SD }\end{array}$} \\
\hline & $\begin{array}{l}\text { Millennials } \\
(n=168)\end{array}$ & $\begin{array}{c}\text { Gen X } \\
(n=185)\end{array}$ & $\begin{array}{c}\text { Baby } \\
\text { boomers } \\
(n=65)\end{array}$ & $F$ & $\begin{array}{l}\text { Diploma } \\
\text { and } \\
\text { below }\end{array}$ & $\begin{array}{c}\text { Degree } \\
\text { and } \\
\text { above }\end{array}$ & $t$ & \\
\hline \multicolumn{9}{|l|}{ Attitude (For me, consuming halal food is) } \\
\hline Extremely unimportant - extremely important & $4.73^{\mathrm{a}} \pm 0.52$ & $4.51^{\mathrm{b}} \pm 0.78$ & $\begin{array}{l}4.56^{\mathrm{ab}} \pm 0.6 \\
6\end{array}$ & $5.09 *$ & $\begin{array}{c}4.57 \pm 0.7 \\
2\end{array}$ & $\begin{array}{c}4.64 \pm 0.6 \\
3\end{array}$ & -1.12 & $4.61 \pm 0.67$ \\
\hline Extremely undesirable - extremely desirable & $4.75^{\mathrm{a}} \pm 0.46$ & $4.53^{b} \pm 0.77$ & $\begin{array}{l}4.63^{\mathrm{ab}} \pm 0.4 \\
\quad 9\end{array}$ & $5.36^{*}$ & $\begin{array}{c}4.60 \pm 0.6 \\
5\end{array}$ & $\begin{array}{c}4.66 \pm 0.6 \\
1\end{array}$ & -0.97 & $4.64 \pm 0.62$ \\
\hline Extremely negative - extremely positive & $4.65 \pm 0.55$ & $4.50 \pm 0.72$ & $4.63 \pm 0.65$ & 2.80 & $\begin{array}{c}4.53 \pm 0.7 \\
1\end{array}$ & $\begin{array}{c}4.62 \pm 0.6 \\
0\end{array}$ & -1.39 & $4.58 \pm 0.65$ \\
\hline Extremely unenjoyable - extremely enjoyable & $4.60 \pm 0.59$ & $4.46 \pm 0.71$ & $4.49 \pm 0.71$ & 2.04 & $\begin{array}{c}4.49 \pm 0.7 \\
1\end{array}$ & $\begin{array}{l}4.54 \pm 0.6 \\
3\end{array}$ & -0.84 & $4.52 \pm 0.66$ \\
\hline \multicolumn{9}{|l|}{ Subjective norms } \\
\hline $\begin{array}{l}\text { People who are important to me think I should eat halal } \\
\text { food }\end{array}$ & $4.42 \pm 0.75$ & $4.35 \pm 0.76$ & $4.48 \pm 0.81$ & 0.73 & $\begin{array}{c}4.33 \pm 0.7 \\
9\end{array}$ & $\begin{array}{c}4.45 \pm 0.7 \\
3\end{array}$ & -1.58 & $4.40 \pm 0.76$ \\
\hline $\begin{array}{l}\text { People who are important to me would approve that I eat } \\
\text { halal food }\end{array}$ & $4.60^{\mathrm{a}} \pm 0.58$ & $4.43^{b} \pm 0.63$ & $\begin{array}{c}4.63^{\mathrm{a}} \pm .0 .5 \\
2\end{array}$ & $4.71 *$ & $\begin{array}{c}4.48 \pm 0.6 \\
0\end{array}$ & $\begin{array}{l}4.57 \pm 0.5 \\
9\end{array}$ & -1.57 & $4.53 \pm .060$ \\
\hline My community / village think I should eat halal food & $4.28 \pm 0.72$ & $4.10 \pm 0.86$ & $4.20 \pm 0.87$ & 2.24 & $\begin{array}{c}4.21 \pm 0.7 \\
5\end{array}$ & $\begin{array}{l}4.17 \pm 0.8 \\
6\end{array}$ & 0.57 & $4.19 \pm 0.81$ \\
\hline I feel under social pressure to eat halal food & $2.20 \pm 1.17$ & $2.20 \pm 1.25$ & $2.34 \pm 1.41$ & 0.32 & $\begin{array}{c}2.24 \pm 1.1 \\
8\end{array}$ & $\begin{array}{c}2.21 \pm 1.2 \\
9\end{array}$ & 0.22 & $2.22 \pm 1.24$ \\
\hline \multicolumn{9}{|l|}{ Perceived Behavioural Control } \\
\hline $\begin{array}{l}\text { Whether or not I consume halal food is completely up to } \\
\text { me }\end{array}$ & $4.25 \pm 0.78$ & $4.16 \pm 0.97$ & $4.25 \pm 0.83$ & 0.55 & $\begin{array}{l}4.10 \pm 0.8 \\
8\end{array}$ & $\begin{array}{l}4.30 \pm 0.8 \\
6\end{array}$ & $\begin{array}{c}- \\
2.30 \\
*\end{array}$ & $4.21 \pm 0.88$ \\
\hline $\begin{array}{l}\text { I am confident that I can find and consume halal food } \\
\text { whenever I want }\end{array}$ & $4.15 \pm 0.82$ & $4.00 \pm 0.97$ & $4.14 \pm 0.92$ & 1.39 & $\begin{array}{c}4.07 \pm 0.8 \\
6\end{array}$ & $\begin{array}{c}4.10 \pm 0.9 \\
4\end{array}$ & -0.33 & $4.08 \pm 0.91$ \\
\hline
\end{tabular}




\begin{tabular}{|c|c|c|c|c|c|c|c|c|}
\hline \multirow[t]{2}{*}{ Factors } & \multicolumn{4}{|c|}{ Age } & \multicolumn{3}{|c|}{ Education } & \multirow{2}{*}{$\begin{array}{c}\text { Overall } \\
\text { mean } \pm \\
\text { SD }\end{array}$} \\
\hline & $\begin{array}{l}\text { Millennials } \\
(n=168)\end{array}$ & $\begin{array}{l}\text { Gen } X \\
(n=185)\end{array}$ & $\begin{array}{c}\text { Baby } \\
\text { boomers } \\
(\mathrm{n}=65)\end{array}$ & $F$ & $\begin{array}{l}\text { Diploma } \\
\text { and } \\
\text { below }\end{array}$ & $\begin{array}{l}\text { Degree } \\
\text { and } \\
\text { above }\end{array}$ & $t$ & \\
\hline $\begin{array}{l}\text { I have resources, time and opportunities to consume halal } \\
\text { food }\end{array}$ & $4.37 \pm 0.64$ & $4.25 \pm 0.71$ & $4.29 \pm 0.82$ & 1.21 & $\begin{array}{c}4.24 \pm 0.7 \\
4\end{array}$ & $\begin{array}{l}4.36 \pm 0.6 \\
7\end{array}$ & -1.65 & $4.31 \pm 0.70$ \\
\hline I am confident I can find and consume halal food easily & $4.23 \pm 0.81$ & $4.04 \pm 0.97$ & $4.05 \pm 0.87$ & 2.39 & $\begin{array}{c}4.08 \pm 0.8 \\
5\end{array}$ & $\begin{array}{l}4.15 \pm 0.9 \\
3\end{array}$ & -0.77 & $4.12 \pm 0.89$ \\
\hline \multicolumn{9}{|l|}{ Intention } \\
\hline I am willing to pay more to consume halal food & $4.16 \pm 0.83$ & $4.23 \pm 0.90$ & $4.35 \pm 0.54$ & 1.26 & $\begin{array}{c}4.08 \pm 0.8 \\
4\end{array}$ & $\begin{array}{l}4.34 \pm 0.8 \\
0\end{array}$ & -3.16 & $4.22 \pm 0.82$ \\
\hline $\begin{array}{l}\text { I am willing to shop around to find and consume halal } \\
\text { food }\end{array}$ & $4.43 \pm 0.58$ & $4.48 \pm 0.57$ & $4.41 \pm 0.53$ & 0.42 & $\begin{array}{c}4.38 \pm 0.5 \\
8\end{array}$ & $\begin{array}{l}4.51 \pm 0.5 \\
5\end{array}$ & -2.33 & $4.45 \pm 0.57$ \\
\hline I intend to purchase halal food in future & $4.49 \pm 0.60$ & $4.45 \pm 0.72$ & $4.49 \pm 0.50$ & 0.21 & $\begin{array}{c}4.35 \pm 0.7 \\
2\end{array}$ & $\begin{array}{c}4.58 \pm 0.5 \\
5\end{array}$ & $\begin{array}{c}- \\
3.63 \\
*\end{array}$ & $4.47 \pm 0.64$ \\
\hline \multicolumn{9}{|l|}{ Perceived awareness } \\
\hline I am personally very knowledgeable about halal food & $3.91 \pm 1.00$ & $3.75 \pm 1.24$ & $3.83 \pm 1.19$ & 0.87 & $\begin{array}{c}3.85 \pm .1 \\
04\end{array}$ & $\begin{array}{l}3.80 \pm 1.2 \\
1\end{array}$ & 0.48 & $3.83 \pm 1.14$ \\
\hline $\begin{array}{l}\text { The average person in East Java is very knowledgeable } \\
\text { about halal food }\end{array}$ & $3.94 \pm 0.82$ & $3.80 \pm 0.91$ & $3.69 \pm 1.03$ & 2.08 & $\begin{array}{c}3.82 \pm 0.8 \\
9\end{array}$ & $\begin{array}{l}3.85 \pm 0.9 \\
1\end{array}$ & -0.30 & $3.84 \pm 0.90$ \\
\hline $\begin{array}{l}\text { The local food industry is very knowledgeable about halal } \\
\text { food }\end{array}$ & $4.09 \pm 0.86$ & $3.99 \pm 0.90$ & $4.09 \pm 0.93$ & 0.66 & $\begin{array}{c}4.00 \pm 0.9 \\
0\end{array}$ & $\begin{array}{c}4.08 \pm 0.8 \\
7\end{array}$ & -0.97 & $4.05 \pm 0.88$ \\
\hline \multicolumn{9}{|l|}{ Habit (Eating halal food is something) } \\
\hline I do regularly & $4.58 \pm 0.56$ & $4.52 \pm 0.62$ & $4.51 \pm 0.60$ & 0.71 & $\begin{array}{l}4.49 \pm 0.6 \\
5\end{array}$ & $\begin{array}{l}4.58 \pm 0.5 \\
5\end{array}$ & -1.52 & $4.54 \pm 0.60$ \\
\hline I do without having to consciously remember & $4.39^{\mathrm{a}} \pm 0.84$ & $4.12^{b} \pm 0.98$ & $\begin{array}{c}4.32^{\mathrm{ab}} \pm 0.7 \\
7\end{array}$ & 4.06* & $\begin{array}{l}4.27 \pm 0.8 \\
5\end{array}$ & $\begin{array}{l}4.26 \pm 0.9 \\
5\end{array}$ & 0.10 & $4.26 \pm 0.90$ \\
\hline I feel weird if I don't do it & $4.41 \pm 0.72$ & $4.40 \pm 0.69$ & $4.46 \pm 0.69$ & 0.21 & $\begin{array}{c}4.32 \pm 0.7 \\
8\end{array}$ & $\begin{array}{l}4.50 \pm 0.6 \\
1\end{array}$ & $\begin{array}{c}- \\
2.56\end{array}$ & $4.41 \pm 0.70$ \\
\hline
\end{tabular}




\begin{tabular}{|c|c|c|c|c|c|c|c|c|}
\hline \multirow[t]{2}{*}{ Factors } & \multicolumn{4}{|c|}{ Age } & \multicolumn{3}{|c|}{ Education } & \multirow{2}{*}{$\begin{array}{c}\text { Overall } \\
\text { mean } \pm \\
\text { SD }\end{array}$} \\
\hline & $\begin{array}{l}\text { Millennials } \\
(n=168)\end{array}$ & $\begin{array}{c}\text { Gen X } \\
(n=185)\end{array}$ & $\begin{array}{c}\text { Baby } \\
\text { boomers } \\
(n=65)\end{array}$ & $F$ & $\begin{array}{c}\text { Diploma } \\
\text { and } \\
\text { below }\end{array}$ & $\begin{array}{c}\text { Degree } \\
\text { and } \\
\text { above }\end{array}$ & $t$ & \\
\hline I don't have to think about doing it & $3.70 \pm 1.30$ & $3.77 \pm 1.26$ & $3.98 \pm 1.21$ & 1.17 & $\begin{array}{c}3.74 \pm 1.2 \\
5\end{array}$ & $\begin{array}{c}3.81 \pm 1.2 \\
9\end{array}$ & -0.49 & $3.78 \pm 1.27$ \\
\hline \multicolumn{9}{|l|}{ Religious self-identity } \\
\hline Eating halal food is an important part of who I am & $4.35 \pm 0.72$ & $4.34 \pm 0.77$ & $4.45 \pm 0.71$ & 0.50 & $\begin{array}{c}4.32 \pm 0.7 \\
7\end{array}$ & $\begin{array}{c}4.40 \pm 0.7 \\
1\end{array}$ & -1.17 & $4.36 \pm 0.74$ \\
\hline I would feel at a loss if I can't consume halal food & $4.27 \pm 0.80$ & $4.33 \pm 0.78$ & $4.40 \pm 0.58$ & 0.83 & $\begin{array}{c}4.18 \pm 0.7 \\
8\end{array}$ & $\begin{array}{c}4.43 \pm 0.7 \\
3\end{array}$ & -3.42 & $4.31 \pm 0.76$ \\
\hline I follow strict Islamic rules and will only eat halal food & $4.36 \pm 0.80$ & $4.33 \pm 0.84$ & $4.46 \pm 0.73$ & 0.65 & $\begin{array}{c}4.28 \pm 0.9 \\
1\end{array}$ & $\begin{array}{l}4.43 \pm 0.6 \\
9\end{array}$ & -1.90 & $4.36 \pm 0.80$ \\
\hline \multicolumn{9}{|l|}{ Moral Obligations } \\
\hline I feel guilty if I do not consume halal food & $4.45 \pm 0.78$ & $4.48 \pm 0.67$ & $4.34 \pm 0.89$ & 0.89 & $\begin{array}{c}4.38 \pm 0.8 \\
2\end{array}$ & $\begin{array}{c}4.50 \pm 0.6 \\
9\end{array}$ & -1.68 & $4.45 \pm 0.75$ \\
\hline I feel morally wrong if I do not consume halal food & $4.44^{\mathrm{a}} \pm 0.74$ & $\begin{array}{c}4.41^{\mathrm{ab}} \pm 0.6 \\
6\end{array}$ & $4.15^{\mathrm{b}} \pm 0.99$ & $3.54 *$ & $\begin{array}{c}4.30 \pm 0.7 \\
8\end{array}$ & $\begin{array}{c}4.45 \pm 0.7 \\
4\end{array}$ & -1.95 & $4.38 \pm 0.76$ \\
\hline $\begin{array}{l}\text { It goes against my principles if I do not consume halal } \\
\text { food }\end{array}$ & $4.32 \pm 0.84$ & $4.32 \pm 0.73$ & $4.26 \pm 0.87$ & 0.15 & $\begin{array}{c}4.26 \pm 0.8 \\
2\end{array}$ & $\begin{array}{l}4.35 \pm 0.7 \\
8\end{array}$ & -1.20 & $4.31 \pm 0.80$ \\
\hline \multicolumn{9}{|l|}{ Trust } \\
\hline $\begin{array}{l}\text { I do not trust that food with international or other halal } \\
\text { logos are halal }\end{array}$ & $2.90 \pm 1.09$ & $2.75 \pm 1.11$ & $2.88 \pm 1.27$ & 0.81 & $\begin{array}{c}2.88 \pm 1.1 \\
1\end{array}$ & $\begin{array}{c}2.79 \pm 1.1 \\
5\end{array}$ & 0.78 & $2.83 \pm 1.13$ \\
\hline $\begin{array}{l}\text { I trust local Muslim sellers who sell halal food even if it's } \\
\text { not labelled halal }\end{array}$ & $3.49^{\mathrm{a}} \pm 1.04$ & $3.23 \pm 1.15$ & $3.21 \pm 1.30$ & 2.89 & $\begin{array}{c}3.41 \pm 1.0 \\
6\end{array}$ & $\begin{array}{c}3.27 \pm 1.1 \\
9\end{array}$ & 1.23 & $3.33 \pm 1.13$ \\
\hline
\end{tabular}

Note: *denotes $\mathrm{p}<0.05$ 
Table 2 Mean composition of items and reliability analysis of TPB components

\begin{tabular}{lcccc}
\hline \multicolumn{1}{c}{ TPB components } & Composition of items & Mean & SD & Cronbach's alpha \\
\hline Attitude & Mean of 4 items & 4.59 & 0.59 & 0.91 \\
Subjective norms & Mean of 4 items & 3.84 & 0.59 & 0.51 \\
Perceived behavioural & Mean of 4 items & 4.16 & 0.70 & 0.82 \\
control & & & & \\
Perceived awareness & Mean of 3 items & 3.90 & 0.71 & 0.52 \\
Habit & Mean of 4 items & 4.26 & 0.63 & 0.63 \\
Religious self-identity & Mean of 3 items & 4.34 & 0.64 & 0.74 \\
Moral obligations & Mean of 3 items & 4.41 & 0.66 & 0.85 \\
Trust & Mean of 2 items & 3.49 & 0.69 & 0.59 \\
Intention & Mean of 3 items & 4.38 & 0.59 & 0.81 \\
\hline
\end{tabular}

